\title{
The Impact of the Value of Religiosity on Buying Decision Making on the Overseas Bugis Community in Jambi
}

\author{
Kurniati Karim $^{1 *}$, Ahmad Hosen ${ }^{2}$ \\ ${ }^{1,2}$ Departement of Management, SekolahTinggi Ilmu Ekonomi Sakti Alam \\ Kerinci, Indonesia \\ * Corresponding author: \\ Email: DIM07.unib@gmail.com
}

\begin{abstract}
.
The Bugis tribe is one of the tribes in South Sulawesi Province, in addition to the Makassar and Toraja tribes, who uphold their religion and become the basis for their behavior. This is in accordance with the Bugis philosophy of "MappesonariDewataseuwae" (surrender to God's will), which means that the Buginese people behave according to the religious values derived from their culture.The Bugistribe inhabit almost all corners of the archipelago, including in Sumatra, especially Jambi. By inhabiting the Jambi area, it is certain that the influence of the local culture will certainly affect the behavior of someone who lives in the area.Considering that, then, the purpose of this study is to analyze the influence of the value of religiosity of the Bugis tribe in Jambi on the decision of purchasing products.To answer the research problem, the data were collected through a questionnaire of 106 people, then analyzed using simple linear regression analysis. The research results obtained, that although the Bugis people have settled in Jambi, Sumatra, but the decision to purchase products is still influenced by the value of religiosity.
\end{abstract}

Keywords: Buying, decision making, religiosity, Bugis, and Jambi

\section{INTRODUCTION}

Consumers will always behave to meet the needs and desires of a product. But it does not stop there, because according to Kasnaeny et al., (2013) who cite the opinion (Engel.JF et al., 1994), that the activity does not stop there, but there are activities in the form of decision making processes that precede their actions . Solomon et al., (2007) states that consumer behavior is an action taken by consumers to obtain, use, and spend the desired product in an effort to satisfy the needs and desires of consumers.

Consumers in making purchasing decisions have differences between one country and another. This is consistent with Hofstade's study, quoted by Karim \& Tajibu, (2019) that the national culture of a country is different, namely Western societies are individualistic, and societies in the East are more Collectivism. The Bugis community in South Sulawesi, upholds togetherness among them, where almost all activities are carried out together and ask for consideration of relatives including in making purchases. With these conditions, if there has been a mixture of cultures, then the behavior of collectivism is still valid or has been individualistic. Culture is the accumulation of values, rituals and norms obtained from their immediate family / community, which in Culture is related to the value of faith from the teachings of religion.

Consumer Purchasing Decisions one of which can be influenced by culture, as written by 
Kotler \& Keller, (2012) that each culture consists of smaller subcultures that include nationality, religion, racial groups, and geographical areas providing more specific identification and socialization for its members. When subcultures grow big and prosper enough, companies often design marketing programs specifically to serve them. This means that consumption is influenced by the values obtained from the beliefs of the religion they profess.

Religion teaches what its followers must and should not do. This teaching produces the values of faith that guide in acting or behaving. According to Asih, (2015), citing Taylor's opinion, 1975, Religion (religion) is an important foundation of culture that influences consumer habits, attitudes, and values. Religiosity (faith) is defined as the extent of knowledge, how strong beliefs, how the implementation of worship and rules, and how deep the appreciation of the religion it adheres to. For a Muslim, religiosity can be known from how far the knowledge, belief, implementation and appreciation of the religion of Islam (Nashori, 2004).

Every religion teaches what its followers must and should not do. This teaching produces the values of faith that guide in acting or behaving. Asih, (2015) cite Taylor's opinion, 1975, Religion is the most important foundation of the culture that religious teachings produce the value of faith, which is religiosity which means knowledge, the firmness of belief, the implementation of worship and rules, and how deep the appreciation of religion is embraced.

Religiosity directly affects the choice behavior of followers, through the rules and taboos taught. For example the tradition of fasting with food purchase patterns, and the purchase of minimal clothing that is taboo or deemed incompatible with people's lives. Thus religious values affect consumer behavior by influencing the structure of the consumer's personality, beliefs, values and behavioral tendencies, and ultimately influence the consumer's choice of consumption. The impact of recruitment value on purchasing decisions on Bugis in Makassar City, South Sulawesi has been carried out by Kasnaeny, (2016) who found that the value of religiosity is crucial in making product purchases, where the main thing to do before buying a product is to pay attention to the halal aspect, the accuracy of the measurements, and the origin of the product.

Relation of religion to the model of consumer purchasing decision making has not been much studied. The lack of religious-based studies, according to Solomon et al., (2007) that culture (religion / norms / morals) is taboo to discuss, for example eating dog meat is taboo in Europe, but not so in Hindu society, so too Eating pork is forbidden for Muslims in Indonesia. Thus any religion guides a person in the right behavior, so that if someone does something based on the teachings of their religion, they are said to have faith, because they practice the values of faith (religiosity). . This was also stated by Delener, 1994, quoted by (Mokhlis, 2010) that it is widely recognized that religion has a strong influence on people's beliefs, personal, identity and value systems, and can have implications for consumption. Thus further proof is needed to examine its relationship with consumer purchasing decisions.

Thus this research will continue the research from Kasnaeny in 2016, but focuses on examining the buying decision-making behavior of Bugis tribes abroad, especially in Jambi, to find out whether the values of the faith (religious value) are also considered by the overseas community in conducting product purchase. However, there are differences in research results shown by Astogini et al., (2011) who say that the level of religiosity does not have a significant influence on purchasing decisions for halal products, resulting in a research gap due to differences in results. Thus, there are gaps to do in research, due to gaps (differences in results) from previous studies, and the absence of research with more specific objects, to complement studies that are general in nature.

In general, there are some differences between this research and previous research and being novelty, namely, this study intends to explore the decision-making behavior of buying by ethnic Bugis ethnic communities overseas, while previous research was only conducted on Bugis tribes who settled in their home region of South Sulawesi. Research related to culture has 
also been carried out by (Ahmed \& Ghingold, (2007), but his research was carried out on Muslim objects in Malaysia.

\section{METHODS}

This research is a quantitative descriptive study, which is to determine the impact of the value of religiosity on product purchasing decision making on the Bugis tribe in Jambi. A sample of 106 people, obtained through snowball sampling techniques with consideration of the spread of the existence of people who come from the Bugis tribe of South Sulawesi in Jambi province. Data obtained through the distribution of questionnaires, which contain indicators of the ritual dimension, the idiological dimension, the intellectual dimension, the experiential dimension, and the consequence dimension of the religiosity of Astogini et.al, (2011). The analysis used is a simple linear regression analysis, by first testing the reliability and reliability of research instruments.

\section{RESULT AND DISCUSSION}

\subsection{Results}

Table 1 shows the characteristics of the respondents. Characteristics based on gender, showed male respondents numbered 59 people and women numbered 47 people. Based on age, most respondents were seen between the ages of 35 to 45 years, age over 45 years, amounting to 26 people, as well as the age range of 20 to 35 years. Meanwhile, respondents aged up to 20 years amounted to 9 people. Based on work, the majority of respondents were housewives by 23 people and entrepreneurs by 19 people. The education level of most respondents came from high school level, and the length of stay in Jambi was 20 years, shown in the following table:

Table 1. Descriptive Statistic

\begin{tabular}{lclc}
\hline Variable & n & Variable & n \\
\hline Gender & & Age & \\
Male & 59 & $>45$ & 26 \\
Female & 47 & $>35-45$ & 45 \\
& & $>20-34$ & 26 \\
& & 20 & 9 \\
Profession & & Education & \\
Farmer & 18 & Postgraduate & 13 \\
entrepreneurs & 19 & Bachelor, & 16 \\
housewives & 23 & Academy & 8 \\
Students & 11 & High School & 43 \\
Others & 10 & Middle & 6 \\
& & School & \\
& & Elementary & 20 \\
Period of & & School & \\
residence & & Variable & \\
1 year to 20 years & 29 & Age & \\
21 years to 40 years & 54 & $>45$ & \\
exceed 40 years & 23 & $>35-45$ & \\
\hline
\end{tabular}

Then the research instrument test is conducted, which is carried out to determine whether all indicators listed in the questionnaire are valid and reliable. Validity test is carried out based on the significant value obtained from correlation analysis, where if the significant value $\leq 0.05$ 
then the research instrument is valid and can be continued to the next process. Likewise, a reliability test was carried out based on the Cronbach alpha value, where if the acquisition value is greater than 0.60 then the research instrument has been realiebel.

Table 2. Test Validity of Research Instruments

\begin{tabular}{lllll}
\hline \multicolumn{1}{c}{ Variable } & Statement & $\begin{array}{c}\text { Pearson } \\
\text { Correlation } \\
\text { (r hitung) }\end{array}$ & $\begin{array}{c}\text { r (signifikant } \\
0.05)\end{array}$ & Information \\
\hline \multirow{4}{*}{ Value of Religiosity } & X1 & 0.780 & 0.000 & Valid \\
$(\mathrm{X})$ & $\mathrm{X} 3$ & 0.829 & 0.000 & Valid \\
& $\mathrm{X} 4$ & 0.823 & 0.000 & Valid \\
& $\mathrm{X} 5$ & 0.783 & 0.000 & Valid \\
Buying Decision & Y1 & 0.803 & 0.000 & Valid \\
Making (Y) & Y3 & 0.849 & 0.000 & Valid \\
& Y4 & 0.821 & 0.000 & Valid \\
& Y5 & 0.792 & 0.000 & Valid \\
& & 0.835 & 0.000 & Valid \\
\hline
\end{tabular}

The validity test results show that all research indicators have a significant value below 0.05 , which means that all research indicators are valid and can be continued in the analysis. Next, Table 3 shows the results of data reliability testing which has been completely reliable, because it exceeds the Cronbach Alpha value limit of 0.60 .

Table 3. Research Instrument Reliability Tests

\begin{tabular}{|c|c|c|c|}
\hline Variable & $\begin{array}{l}\text { Reliabilitas } \\
\text { Coefficient }\end{array}$ & Alpha & Information \\
\hline $\mathrm{X}$ & 5 statement & 0.862 & Reliabel \\
\hline Y & 5 statement & 0.873 & Reliabel \\
\hline
\end{tabular}

\section{Regression Analysis}

Simple regression analysis is used to determine the magnitude of the impact of the Value of Religiosity on Product Purchasing Decision Making in the Bugis Community in the city of Jambi. The results of the regression analysis are as follows:

Tabel 4. Regression Analysis and Correlation

\begin{tabular}{|c|c|c|c|c|c|c|c|}
\hline \multirow[t]{2}{*}{ Model } & \multicolumn{3}{|c|}{ Unstandardize Coefficients } & \multirow{2}{*}{$\begin{array}{l}\text { Standardized } \\
\text { Coefficients } \\
\text { B }\end{array}$} & & \multirow[t]{2}{*}{$\mathbf{t}$} & \multirow[t]{2}{*}{ sig } \\
\hline & B & Std.Error & & & & & \\
\hline Constant & .380 & .229 & & & & 0.099 & 0.099 \\
\hline $\mathrm{X}$ & .845 & .054 & & .837 & & 0.000 & 0.000 \\
\hline $\mathbf{R}$ & R Square & $\begin{array}{l}\text { Adjusted } \\
\text { Square }\end{array}$ & $\mathbf{R}$ & $\begin{array}{l}\text { Std.Error } \\
\text { Estimate }\end{array}$ & The & & \\
\hline .837 & .701 & .698 & & .43501 & & & \\
\hline
\end{tabular}

Table 4 shows the regression coefficient $\mathrm{X}$ of 0.845 and has a positive value, meaning that the value of Bugis religious religiosity has a positive influence on product purchasing decisions, which means that the stronger the value of religiosity is owned by the community, the further the decision making process in purchasing products.

Significance value obtained is 0,000 which means that the value of religiosity has a significant impact on purchasing decisions, with a correlation value of 0.837 which means that there is a strong relationship between the value of religiosity with purchasing decisions. Rare 
value of 0.698 means that 69.8 percent of purchasing decisions are influenced by the value of religiosity and 30.2 percent is influenced by other variables not examined in this study. Thus the value of religiosity has a significant positive effect on product purchasing decisions by the Bugis tribe people in Jambi.

\subsection{DISCUSSION}

Religiosity is the process of internalizing religious values in individuals, where internalization is related to beliefs in religious teachings both in the heart and in speech (Ma'zumi et al., 2013). The value of religiosity for the Bugis community has been implemented from generation to generation, which is reflected in the obedience of ancestors, parents, and their families in carrying out religious teachings and implementing these teachings in everyday life. The Bugis community in South Sulawesi is the majority Muslim community. Bugis family life cannot be separated from the role models taught by ancestors or parents directly. The implementation of any activity is always based on the Bugis philosophy which after the entry of Islam became increasingly adhered to. Kotler, et al, (1999) states that the behavior of purchasing decisions on products can be influenced by culture in which the value of faith includes indicators of cultural variables.

Based on descriptive statistical values on the variable value of religiosity, shows that Bugis respondents have a good value of faith, seen in the Likert scale score of 4 , and decisions based on the value of religiosity are sufficient considerations in purchase decisions making.

The calculation results show that there is a significant positive effect between the value of religiosity on purchasing decisions of overseas Bugis communities in the city of Jambi. This means that the increasing value of community religiosity will increase the purchase decision on a product that is believed to be useful and lawful, and if the community lacks an understanding of the value of religiosity then does not consider it in making their decision to buy a product.

The analysis shows that even though the Bugis people who have moved to Jambi Province, Sumatra, their buying behavior still shows the same thing as the Bugis people in South Sulawesi as their origin. The Bugis in Jambi still practice the value of their faith even though they have lived for decades. This is most likely due to the cultural background of Jambi which is religiously and predominantly Muslim, and also comes from the Malay family. However, this still needs a deeper study of further research. Cultural similarity, although different locations cause the value of religiosity to influence people's behavior when deciding to buy their products.

Religiosity is how far a person practices his belief in a religion that is embraced in daily life. This belief then becomes the basic foundation of the Bugis community in making decisions for the purchase of products that will be consumed daily. Respondents buy a desired product based on what is obtained from their knowledge of religion. Meanwhile, adherence to one's religion also provides instructions for choosing a product. The value of religiosity directs consumers in determining what is feasible or unfit for consumption so that it becomes the basis in making purchasing decisions. Thus the factor of religiosity has a strong influence on the decision of the Bugis in choosing products.

The Bugis community believes that belief in living a religious ritual will lead them to behave. This belief dimension shows the level of Muslim consumer confidence that comes from the Bugis towards the truth of religious teachings, especially those that are fundamental and dogmatic. In Islam, this dimension is related to the pillars of faith which contain six beliefs, namely trust in the Essence of Allah SWT, believe in angels, believe in the Apostles of Allah SWT, believe in the Books sent down by Allah SWT, believe the coming of doomsday, and believe in the destiny of Allah SWT. This is the core of this belief dimension. Based on these dimensions, it becomes the basis for daily behavior, where a person will avoid things that are prohibited by religion for fear of sin. Likewise the choice of a product based on fear of sin will be obtained in the days to come. The teachings about a person's religion also determine the 
good and the bad of a product, which is appropriate for use in daily life, or whether it is lawful or not lawful of a product. When the teachings of the faith state that a product is not halal for consumption, then whether or not the followers will carry out the need to question it more deeply, because the teachings of religion are teachings about the good for humans. Following without consideration does not mean an attitude that is just accepting, but because someone already understands the teachings of his religion that has taught what is permissible and what cannot be accompanied by reasons.

The ability of respondents or consumers to make decisions based on the value of religiosity is also determined by their intellectual abilities. This means that product purchases are carefully considered based on their benefits. Decision making requires consideration, both in terms of price in relation to income, the decision of the magnitude of the benefits compared to the costs incurred, so as not to make someone wasteful in making product purchases.

Respondents' knowledge gained from religious learning is sufficiently considered in the product purchase decision. Knowledge of suitable products are purchased according to religious teachings and products that may not be consumed and prohibited by religious teachings. Thus the respondent knows the reasons related to why a product can be consumed and why there are products that should not be consumed. The many considerations in making product purchasing decisions are due to the consequences that must be accepted by consumers related to religion. Consequences are the final result or impact of an activity or act carried out. This impact can be positive or negative for yourself, others, activities, situations, or the environment.

According to Glock and Stark (1966) in Riadi, (2018) religiosity is the level of one's conception of religion and the level of one's commitment to his religion. The level of conceptualization is the level of one's knowledge of his religion, while what is meant by the level of commitment is something that needs to be understood as a whole, so that there are various ways for individuals to become religious. Based on the research findings, the results of this study support research conducted by (Gibbs et al., 2007), Mustafa, (2011), and Kasnaeny, (2016), who concluded that religious factors, in this case the value of religiosity has a significant effect on product selection. The results of this study also strengthen the theory which explains that culture influences purchasing decisions, while one indicator of culture is religion. This happens because the level of community religiosity is the basic foundation in choosing savings products. This research also shows that although the Bugis people have migrated to Jambi Province, they still consider the value of religiosity taught by religion and their ancestors from their area of origin. Thus this study shows the similarity of the results with Kasnaeny's research (2016) which examines product purchase decisions based on Makassar's Bugis culture in Makassar City, that the Bugis community in Makassar as the capital of South Sulawesi uses product consumption based on considerations of religious value.

\section{CONCLUSION}

The conclusion from this study is the value of religiosity has a significant positive effect on product purchasing decisions by the Bugis community in Jambi. This finding means that the Bugis people overseas even though they have long lived outside the Bugis region but still consider the value of religiosity in purchasing products. Thus, this information is important for marketers in the Jambi area to promote products by paying attention to cultural characteristics related to consumer religiosity in shopping.

\section{ACKNOWLEDGMENTS}

The authors would like to thank RISTEKDIKTI for supporting this project, to STIE ALAM Kerinci for providing support for this research. We also thank the people of Jambi, Bengkulu Province. 


\section{REFERENCES}

[1] Ahmed, Z. U., \& Ghingold, M. (2007). Malaysian shopping mall behavior: an exploratory study. Journal of Marketing, 19(4), 331-348. https://doi.org/10.1108/13555850710827841

[2] Asih, D. (2015). Dimensi-Dimensi Spiritualitas Dan Religiusitas (Issue OCTOBER) [Universitas Gadjah Mada]. Https://Doi.Org/10.13140/RG.2.1.3375.1765

[3] Astogini, D., Wahyudin, \& Wulandari, Dan S. Z. (2011). Aspek Religiusitas Dalam Keputusan Pembelian Produk Halal (Studi Tentang Labelisasi Halal Pada Produk Makanan Dan Minuman Kemasan). Jeba, 13(1), 1-8. https://doi.org/10.1017/CBO9781107415324.004

[4] Gibbs, P., Ilkan, M., \& Pouloukas, S. (2007). The ethics of marketing in Muslim and Christian communities: Insights for global marketing. Equal Opportunities International, 26(7), 678-692. https://doi.org/10.1108/02610150710822311

[5] Karim, K., \& Tajibu, M. J. (2019). TRADISI MAPPASSILI SEBAGAI SALAH SATU PENENTU KEPUASAN KONSUMEN BUGIS-MAKASSAR PASCA PEMBELIAN PRODUK DI KOTA MAKASSAR. Jurnal Bisnis Dan Manajemen (Bisma), 13(1), 4351. https://doi.org/https://doi.org/10.19184/bisma.v13i1.8817

[6] Kasnaeny, K. (2016). Customer Decision Making Style , Based On Bugis - Makassar Culture in Indonesia. International Journal of Business and Management Invension, 5(3), 1-6. https://www.ijbmi.org/papers/Vol(5)3/Version-2/A503020106.pdf

[7] Kasnaeny, K., Sudiro, A., Hadiwidjojo, D., \& Rohman, F. (2013). Patronage Buying Motives of Coffee shop's Consumers. IOSR Journal of Business and Management, 8(3), 19-22. http://iosrjournals.org/iosr-jbm/papers/Vol8-issue3/D0831922.pdf

[8] Kotler, Philip, Gary Amstrong, John Saunders, V. W. (1999). Principles Of Marketing (Second Eur). Prentice Hall.

[9] Kotler, P., \& Keller, K. L. (2012). Marketing Management. In S. Yagan (Ed.), Prentice Hall (14th ed., Vol. 22, Issue 4). Prentice Hall. https://doi.org/10.1080/08911760903022556

[10] Mokhlis, S. (2010). Religious Contrasts in Consumer Shopping Styles : A Factor Analytic Comparison. Journal of Business Studies Quarterly, 2(1), 52-64. https://doi.org/doi=10.1.1.652.2998

[11] Mustafa, L. (2011). Emotional Intelligence Determining Work Attitudes and Outcomes of University Teachers : Evidence from Pakistan. Business, 240-260.

[12] Nashori, F. (2004). Menjadi manusia kreatif. Indonesian Psychologycal Journal, 1(1), 15. https://pdfs.semanticscholar.org/

[13] Riadi, M. (2018). Fungsi, Dimensi dan Faktor Yang Mmepengaruhi Religiusitas. In KajianPustaka.com. https://www.kajianpustaka.com/2018.

[14] Solomon, M., Bamossy, G., Askegaard, S., \& Hogg, M. K. (2007). Consumer Behaviour: A European Perspective. In Pharmacy world \& science : PWS (Fifth Edit, Vol. 29, Issue 1). Original fifth edition, entitled Consumer Behavior published by Prentice-Hall, Inc.,. https://doi.org/10.1007/s11096-005-3797-z 